\title{
報 告ব
}

\section{農村計画に遺した竹中肇教授の足跡}

\author{
佐久間 泰 一*
}

\section{I はじめに}

昨年 5 月東京大学農学部元教授竹中肇先生が急 逝されてから，はや一年になろうとしている。筆 者をはじめ，竹中先生に指導を受けた研究者たち は，大きな虚脱感を追い払えないでいる。竹中先 生が，体系化を目指したにもかかわらず，やり遂 げ得なかった仕事は、これから我々が補足しなけ ればならないであろう。一周忌を迎えて，その作 業の踏み台とするために，竹中先生が農村計画の 分野に遺した足跡をふり返り，その業積を整理し てみたい。

竹中先生の農村計画の分野での研究活動は, 農 村総合整備, 農村定住, 土地利用の 3 つの領域に 分けられると思われる。それらは，昭和50年代に なって始まったもので, それまでの研究内容の帰 結として研究し始めたというものではなく，時代 の流れを感じとって，新しい分野を研究範囲に取 り込んだという性質のものである。政策上の需要 に対応した生きた学問を目指す竹中先生の研究態 度が, 自ずとそうさせたのであろう。

農村計画の分野での竹中先生の研究活動は, 前 述のように，その歴史が浅く10年足らずであるか ら，体系的にまとまっているとはいまだ言い難 い。したがって，3つの各領域において，政策と の対応をみながら, 竹中先生の研究活動を整理 し, 主要な論文の内容を紹介する。

筑波大学農林工学系

\section{II 農村総合整備}

明治32年耕地整理法が制定されて以来80年以上 にわたって，わが国の農業土木は，灌溉排水，区 画整理, 農地開発など農業生産の土台となる農地 の改良にかかわってきた。

ところが, 戦後の経済成長の結果, 農村の大部 分は農家より非農家がはるかに多いという混住化 社会になった。そして, 非農家の家庭雑排水が用 水路に流れ込み用水路が污染される，村落共同体 が弱体化し祭がすたれるとか消防団が編成できな いなどの多くの問題が現われ，都市に比べて農村 の生活環境の劣悪さが顕著になった。

こうして, 昭和40年代になって, 農業土木の技 術者・研究者の間で, 農村の生活環境の整備の必 要性が叫ばれ, 農林水産省は昭和47年に農村基盤 総合整備パイロット事業 (総パ事業), 昭和 48 年 に農村総合整備モデル事業 (モデル事業)，昭和51 年に農村基盤総合整備事業（ミ二総パ事業）と, 立て続けに新しい事業を創設した。これらの事業 では, 生活環境の整備が, 㽚場整備, 農道整備や 用排水路整備とともに実施されることになった。

この領域での竹中先生の研究活動は, 各種委員 会のメンバーとしての活動が中心である。

竹中先生が農村総合整備に取り組み始めたのは 昭和51年で, 農村地域整備計画調査委員会の委員 としてであった。この調査は, 当時設置されたば かりの国土庁の委託を受けて行われた。

この調査に基づいて，佐藤洋平らとまとめた論 
文が「農村整備におけるニーズと整備水準 2)」(農 業土木学会論文集76号1978年) である。

この論文では, 昭和 48 年度から昭和 50 年度まで に農村総合整備計画書を作成した 350 の市町村を 対象にアンケート調査とその整備計画書を資料と して使用して, 農村整備のニーズを分析してい る。

まず, 各市町村を, 人口増加地域と人口減少地 域とに分類し，前者からは山村地域と過疎地域を とり出し, 後者からは都市化地域をとり出すとい う, 人口動態に着目した方針で類型化を行い, 都 市型, 密住型, 疎住型, 過疎型, 山地村型の 5 つ のグループに分けている。このグループごとに， 発展の方向, 環境整備の状況や農村整備における ニーズと整備水準の 3 点を分析した。

発展方向については, 各市町村の整備構想か ら，農業生産のための環境づくりとともに生活環 境を整備し, 農業生産の拡大を図る「純農村指 向」, 農業に重点を置きつつも在村通勤の田園居 住地としての機能を期待する「混住空間整備」, 農業との調和を重視しつつ工業の導入を図る「農 -工併進」, 自然休養村や観光農園などのレクリ エーション空間を創る「余暇空間開発」, 都市住 民の憩いの場として緑の保存・維持を図る「自然 環境保全」に分け，この 5 つの発展方向を各グル ープがどのように選択しているかを分析してい る。次に, 農振地域の居住空間を各市町村がどの ように考えているかについては, 地域社会の目指 す方向でとらえて，4つの方向に分類した。すな わち，ある程度の人口減少はやむをえないものと し，農業生産を営む場として地域社会を再編・整 備しょうとする「農業者専住」, 人口を現状維持 し，その地域に育った人による地域の再生をはか ろうとする「ふるさと再生」, 既存集落内に人口 流入を図り，農業者と非農業者の隔和した新しい 混住社会の形成を目指す「混住社会」, 二ュータ ウンをつくり, 人口流入を促進するが, 既存集落 とは分離した形で地域社会の形成を目指す「二ュ ータウン」の 4 つの方向を, 各グループがどのよ うに選択しているかをまとめ，それぞれの指向型 を各グループが選好する強さはそれぞれの人口動 態によく対応していることを明らかにした。
環境整備の状況については，農業用水施設や農 業排水施設など 9 項目の生産関連諸整備項目と水 道施設や下水道など16項目の生活関連諸整備項目 の計25項目の整備状況を,「非常によい」,「よい」, 「普通」,「悪い」, 「非常に悪い」の 5 段階の評価 で調査し，それを，それぞれ+2, + $1,0,-$ 1 ，-2というように数量化してまとめて，各グ ループごとに図示している。その結果,「山地村 型」における農業生産基盤の整備の低位なこと,

「都市型」に見る医療施設の整備状況のよさに比 較して, 他の 4 グループでの整備状況の低さを指 摘した。

ニーズと整備水準については，25の各整備項目 に対する整備要求の強さを農村整備におけるニー ズの程度とみなして，「緊急に」、「急いで」，「い ずれは」の 3 段階の整備要求を数值化しランキン グすることによって, 農道, 集落内道路, 園地・ 遊び場・スポーツ施設, 次いで, 農業排水施設, 農業集落排水施設が要求度の高いものであること を導き出している。さらに，農村整備のミニマム な水準をひき出すために，農村環境の整備に対す る要求の強さと農村環境の現状評価とをクロス評 価してランクをつける。その結果, 農業用水施 設, 農業排水施設, 圃場整備, 農道の 4 つの生産 関連項目が, そして, 水道, 集落内道路, 園地 遊び場・スポーツ施設の 3 つの生活関連項目が, 各グループに共通のミニマムな水準としてクロー ズアップされることを明らかにした。

このように, 都市型, 密住型, 疎住型, 過疎 型, 山地村型の 5 つのグループについて, さまざ まな試みが, 各グループの農村整備像を浮かび上 がらせようとして行われているが, そのイメージ は必ずしもはっきりとしたものとなっているとは 限らないので, この試みは必ずしも成功していと は言えないが, 今後の農村整備の事例研究の方向 を切り開いたのではなかろうか。論文の最後で, 施設の建設のようなハードウェアの面の整備だけ でなく，その施設を生かしていくための運営シス テムの検討, あるいはサービス供給のための地域 システムの形成というソフトウェア面の整備の必 要性を指摘している点は注目されてよい。

この論文が発表された昭和53年には, 農業土木 
学会の計画基準改訂委員会の農村環境整備部会の 委員を引き受け，3ケ年にわたって勤めた。

昭和 55 年からは, 毎年委員会として活発に各種 の委員会活動を行った。

昭和 $55 ， 56$ 年には，再び国土庁の委託による農 村総合整備計画の成果に関する調査中央委員会で 活躍した。

ここでもアンケート調査を実施していて，それ を大石純夫と分析した報告が、「農村総合整備の 今後の方向について ${ }^{7)} 」($ 農村計画学会誌 1 巻 2 号1982年）である。

アンケートは, 昭和 54 年までに農村総合整備計 画を策定した676市町村に対し悉皆的に行われ， それまでの農村総合整備を総括している。

アンケート調査の報告は, まず, 農業振興地域 における発展方向，農村総合整備計画の策定動 機, 整備計画の策定の配慮, 住民意向を把握する 方式，整備計画をまとめるうえでの苦慮，農村総 合整備計画の活用状況, 農村総合整備計画策定の 副次的効果, 新たな整備内容の重点, 事業化につ いての希望と実施状況の 9 項目について単純集計 した結果が述べられる。整備計画の策定の配慮の 分析の結果, 土地利用計画に対する配慮が極めて 薄く，もっと積極的に土地利用のあり方を配慮す べきだという主張が提出されている。事業で実施 されかつ今後も実施希望の多いものは, 道路, 飲 雑用水施設, コミュニティ施設であるという。こ れは，前述の論文「農村整備におけるニーズと整

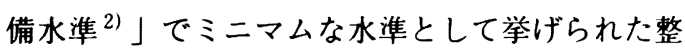
備項目とほほ同じである。

次に前述の論文と同様に, 人口動態に着目し

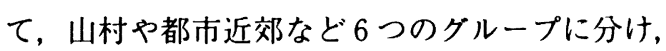
それぞれの類型について, 人口規模, 農業振興地 域における農業振興方法および発展方向, 農村総 合整備計画の策定動機, 農村総合整備構想におけ る配慮, 整備計画の策定にあたっての配慮, 農村 総合整備計画をまとめる上での苦虑, 農村総合整 備計画策定の副次的効果, 農村総合整備計画を策 定すべき範囲，新たな整備内容の重点の 9 項目に ついて集計，考察がなされている。

以上を総括して, 農村総合整備計画には，地域 の特質があまりみられず，いずれも平均的な計画
となっていると批判している。今後の農村整備に 対しては, (1)農家と非農家の相互理解が大切であ る。(2)地域の中で自然発生的に輩出してくるリー ダーを大切にする; (3)住民の総意を優先し，かつ 地域内で集落間のバランスをとるように行政指導 する，(4)施設の管理運営は住民が自主的に行なう などを留意すべき点として挙げている。

昭和57，58年には，農林水産省の委託で，農村 総合整備関連施設地域管理運営調査検討委員会を 指導した。

ここでは, 農業集落道, 集落排水施設, 集落排 水処理施設, 集落防災安全施設, 農村環境改善七 ンター, 農村公園などの管理運営について, アン ケート調查と現地調査を行い, その現況の把握と 将来の維持管理のあり方を検討している。

竹中先生は, この調査の結果を, 論文にまとめ ようと考えていたのではなかろうか。

竹中先生は, 農村総合整備に関する調査以外の 方面にも活躍していた。農村総合整備事業が10年 目を迎えた昭和56年には，全国土地改良事業団体 連合会が主催する農村総合整備コンクールが開始 されたが, 竹中先生は, 10人の委員から成る中央 選定委員会の委員長として審査に当たり,コンク 一ルを成功させた。全国土地改良事業団体連合会 が発行している雑誌「村づくり」に, 竹中先生が 書いた講評をみると, 前述の論文「農村総合整備 の今後の方向についで!」で考察したことが生か されていて, 地域の特性を踏まえた農村整備の手 法を確立し, 高生産性農業の実現および魅力ある 村づくりを推進することを奨励している。

農村総合整備コンクー几の審査会と併行して, 昭和56年からは「新しい村づくり」の編集委員会 委員長もつとめられた。

以上のような研究その他の活動を通して, 農村 総合整備の重要性を把握したことが,「土地改良 事業の総合的性格 ${ }^{6}$ )」(農業土木学会誌 51 巻 3 号 1983年）から読み取れる。これは, 農業土木学会 誌の巻頭言の依頼をうけて執筆されたもので, こ の小論に, 竹中先生の広範囲にわたる研究活動の 特質がよく表現されている。

灌溉排水事業, 煵場整備事業および農村総合整 備事業を, 土地改良事業の 3 本柱とみなして，そ 
れぞれが有機的に結合されるべきであると考え, 土地改良事業の「総合的性格」というユニークな 見方を提出している。そして，土地改良事業を， 農民の定住化を確実化することを通じて国土資源 の保全と有効利用の基礎を固めるものとして性格 づけている。

この総合的性格は、これから一層深く追究する 意図をもっていたのではないだろうか。このこと は教授時代後半10年の課題として，そうした性格 の枠組のもとに「農地工学技術体系」の出版を構 想していたことにもうかがえるように思われる。

\section{III 農村定住}

農村における定住の問題は，国土開発計画と不 可分であるから，まず，国土開発計画に関する政 策を、日本の経済が高度成長し始めた頃から竹中 先生が定住問題に関わるまで概観してみたい。

日本の経済は, 昭和 30 年頃に復興しやがて高度 成長を10年以上続けた。これを促進した政策は昭 和37年に策定された全国総合開発計画（一全総） である。一全総では，それまでの総花的な全域開 発方式を反省し, 拠点開発方式がとられた。すな わち，大規模な開発拠点として，主として工業の 集積などによって周辺を開発する工業開発拠点 (新産業部市) と, 東京, 大阪, 名古屋のもつ外 部経済の集積を利用しにくい地域の飛躍的な発展 を可能にする中枢主導的な役割をもつ地方開発都 市を設定して, 開発を進めようという計画であっ た。

しかし, 高度成長の過程において, 東京, 大 阪, 名古屋に代表される高密度地域には過密現象 が、その他の低密度地域には過疎現象が生じ，こ れを解決しようとして, 昭和 44 年に新全国総合開 発計画 (新全総) が策定された。この新全総で は, 拠点開発方式の拡充と深化を目指して, 拠点 都市間を結ぶ交通・通信体制の整備をはじめとす る大規模開発プロジェクトが計画される一方で, 地域開発のための基礎単位としての広域生活圈の 構想が打ち出された。

しかしながら，国土の乱開発とも批判された開 発によって環境問題が全国的に生じ, かつ過疎過
密問題が一層深刻するなかで, 新全総が策定され てから 3 年も経たずに見直され，やがて全面的に 改定されることになって, 昭和52年に第三次全国 総合開発計画が登場した。ここでは, 公害や自然 破壊をもたらした都市・工業の開発を反省して, 地方の中小都市を中心とする定住圈構想が提示さ れた。すなわち，50〜100世帯からなる居住区， 小学校区を単位とするコミュニティ形成の基礎と なる定住区, 定住区が複合して形成される定住圈 と 3 段階の生活圈を考え，地域の特性を生かした 生活圏の整備を図ろうとするものであった。

竹中先生が関心を示したのは,この定住圈構想 である。定住圏構想は，大まかに言えば，大都市 への人口集中に歯止めをかけ，農村に人間を住ま わせるために，農村の居住環境を改善するという ものである。したがって, 農村総合整備に取り組 み始めて間もない竹中先生とって, 定住構想に関 心が向くのは当然のことであった。

三全総が策定された翌年の昭和53年に, 富山県 の委託による農村定住条件整備検討委員会の委員 長として調査を指導した。報告書では，富山県研 波地域を対象に，648人のアンケート調査を実施 し, 地域整備の基本方向, 農村地域整備の進め方 を検討するとともに，農村定住の条件を探ろうと した。

この仕事を遂行したからこそ，前章で紹介した 「土地改良事業の総合的性格 ${ }^{6)} 」 て ゙$ 述べている農 民の定住化という言葉が単なる借りものの文句で なく, 内容をもった説得力のある言葉として浮か び上がってくるのである。

\section{IV 土地利用}

土地利用における竹中先生の業績を述べる前 に，予備的に土地分級と法定土地利用計画につい て触れておきたい。

農林省農林水産技術会議事務局編「土地利用区 分の手順と方法」(1964年農林統計協会) による と，土地利用区分のために土地分級の在り方とし て, 自然立地的土地分級, 土地改良技術的土地分 級，交通立地的土地分級を挙げている。

土地利用規制に関する法律の主なものは，都市 
計画法, 農業振興地域の整備に関する法律（農振 法）であり，これらの法律による土地利用計画の 上位計画として，国土利用計画法による国土利用 計画がある。

昭和43年に制定された都市計画法によれば，都 道府県知事はまず，都市計画区域を設定し，その 区域を，市街化区域と市街化調整区域に二分す る。市街化区域とは，寸でに市街地を形成してい る区域およびおおむね10年以内に優先的かつ計画 的に市街化を抑制すべき区域のことである。

農振法は，昭和44年に制定され，都道府県知事 が，農業振興地域（農振地域）を設定することと している。農振地域は，相当長期（おおむね10年 以上）にわたって総合的に農業の振興を図るべき 区域である。市街化区域を含めることはできない が, 純農村地域ばかりでなく市街化調整区域に対 しても積極的に指定さる地域である。

昭和49年に制定された国土利用計画法は，3つ の要素から構成されている。第一は，国土利用計 画および土地利用計画に関するものであり，第二 は，土地に関する権利の移転などに関する許可ま たは届出に関する部分であり，第三は，遊休土地 の利用促進に関する部分である。第一の土地利用 計画に関して最も重要な点は, 都道府県知事に, その都道府県の区域内を, 都市地域, 農業地域, 森林地域, 自然公園地域, 自然保全地域に区分す る土地利用計画をたてることを義務づけた点であ る。この法律による国土利用計画が，昭和51年に 策定されている。

この国土利用計画法に触発されたのであろう か, 竹中先生は, 富田正彦と共同で，国土利用の 観点から農地と林地の関係を考え，「国土利用動 向に沿う林野と農地の関係 ${ }^{1)}$ (農業土木学会誌 45 巻 3 号1977年）を書いた。

この論文では，まず，社会が農業または農地に 何を期待するかという点から，農業または農地に 対する社会の見方には, 輸入物と合わせて社会の 食糧需要をまかなうという食糧問題視座, 農外収 入と合わせて農家の家計が他産業従事者と眉を並 べるという農家経済視座, 国土環境の保全と計画 的維持・改善に重要な役割を果たすという国土環 境視座の 3 つの視座があることを提示する。そし
て, 現在の農地開発事業の性格, 日本農業は自給 率を向上できるか，林業と農地開発は調和できる かの 3 点について論じている。

農地開発については, 農用地開発事業, 広域農 業開発事業, 畜産基地建設事業による開畑を論 じ, 北海道での事業は，農業経営の構造改善に寄 与しているが, 都府県での事業は, 交通利便をよ くし, 水管理農業労力を軽減することで兼業経営 をより安定させるという農村整備事業的性格が強 く，食糧自給率向上にはあまり寄与していないこ とを明らかにした。

自給率向上の問題については，500万ha 近くの 農地が永久に残ると予想し, 安定兼業農家の組織 化よりはむしろ専業農家の経営規模拡大が進み, その拡大された経営規模で「水稲〜ムギー牧草」の 2 年 3 作型輪作をやれば, 自給率が向上するという 武田邦太郎の見方に同調を示している。そのために 必要な農業土木の事業は, 第一に, 大型機械化体系 にマッチする区画の新規準を見出すことと水田を 輪作可能な場に整備することであり，第二に，開畑 に関する土工的, 営農組織工学的技術問題を解決 することであるという。第二の必要事項について は,そのモデルとして山林地に一万数千 ha の八郎 潟規模での開畑農村を造るという案を提出した。

林業と農地開発との調和については，鎌田悦男 が提案した構想，すなわち立木と草地を等高線に 沿うベルト状に区分し，ベルト単位で利用を交互 に転換するという「ニュー混牧林」の構想の実現 を期待し，農業土木が，浅海から山林にいたるす べての国土に責任を持てる技術にならなければな らないと主張している。

この論文の延長線上で,「農村整備から農業地 域再開発 ${ }^{5)} 」($ 農業土木学会誌1984年) を, 後に 書いている。

次に竹中先生が手䋰けた仕事は，農村の土地利 用計画のための土地分級の研究である。前述の 「土地利用区分の手順と方法」における土地分級 の研究成果は, 現在の土地利用計画に対処するに は不十分であるという認識から，土地改良技術的 土地分級について, 昭和51年から 3 年間文部省科 学研究費を得て, 共同研究を行った。この成果は 単行本「土地分級」（1981年農林統計協会）とし 
て出版されている。竹中先生は, 山路永司らと共

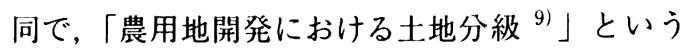
章を執筆している。

昭和56年には, 広田純一らと共同で「農振白地 農用地発生要因の分析 ${ }^{3)} 」 と 「$ 優良農用保全の 観点からのゾーニングのための土地利用区分手 法 $^{4)} 」 の 2 つ の$ 論文を, 農業土木学会論文集に発 表している。後者は, 昭和 54 年度文部省科学研究 費試験研究の一環として行なわれたものの成果で ある。この頃から竹中先生の関心は, 土地分級ば かりでなく，土地利用規制にも拡がっていった。

そして, 逝去された昭和59年には, 広田純一ら と共同で「農振農用地区域の決定メカニズムの分 析 $^{8)}$ (農業土木学会論文集109号1984年) を発表 した。

ここでは, 都市計画法と農振法に基づくゾーニ ングの直接の機能は, 一定期間に一定範囲の土地 において, 都市的土地利用の立地を抑制もしくは 促進することにあるとし, ゾーニングが効果的に 機能しないケースとして, 区域の設定そのものが 適切に行われない場合を取り上げて, 農振地域内 の農用地区域の決定メカニズムを、区域決定の過 程を追跡することによって分析している。

ゾーニングの際には, 土地の所有または利用に よって何らかの受益を期待する複数の主体が, 自 分の期待する受益に有利な区域設定を要求するの で，異なる区域設定要求が競合する場合には，そ の競合と調整の過程を規定する要因を明らかにす るという点に, 分析の視点をおいた。

取り上げた事例は, 栃木県大田原市南金丸中部 地区, 同市加治屋地区, 同県塩原町下田野地区の 3 つである。調査は, 栃木県庁, 大田原市役所, 塩原町役場, 関係土地改良区, 関係農家など多岐 にわたるヒアリングを行っている。

調査の結果によると, 区域設定要求が競合する のは, 原案作成段階と原案修正段階の 2 つの場合 があるという。それぞれの段階での対立事例が紹 介され, 農地が農用地区域から除外された過程が 詳述されている。その結果は, (1)農用地区域は, 除外すべき土地を除いた結果として決定される， 除外の要求は, 市町村原案の作成段階では市町村 の都市計画を中心とする非農業部門から出され,
また原案修正段階では農家から出される, (2)非農 業部門および農家からの除外要求は，ほとんどの まま受け入れられることが多い，ただし，後者の 場合には，市町村の対応いかんによって差が生じ うる, (3)区域設定要求（除外要求を含む）の基本 的な動機は, 土地の所有または利用に基づく利益 に対する期待である，というように要約される。

ついで区域設定要求の競合と調整のメカニズ 么, 利害の均衡化, 土地の利用一体性確保の 3 点 が考察されている。

市町村の農振担当者, 都市計画担当者, 土地所 有農家の 3 つの受益主体（ないしはその代弁者） の行動様式をそれぞれ考察し，区域設定要求と調 整のメカニズムは，(1)より多くの受益を期待しう る優良地であるほど，また特定の区域の有利性が 相対的に高いほど，その区域の設定に固執する，

(2)都市的利用を目的とする場合には，農用地区域 に設定されるか否かによる受益の度合いが著しく 異なるのに対し，農業的利用を目的とする場合は それほどでもないので, 除外支持側の要求の方が 優先されやすい, (3)特定の受益主体（ないしはそ の代弁者）にのみ優良な土地では，区域設定要求 は競合しないあるいは競合してもその程度は弱 い, (4)複数の受益者（ないしはその代弁者）にと って優良な土地では競合が生じ，他にその受益を 期待しうる土地をもつ側が讓歩する傾向にある, の 4 点にまとめられている。これがこの論文の根 幹であろう。

同一集落内の農家あるいは立地条件の似かよっ た集落の間では, 利害の均衡化とでもいうべき作 用が働くことがあり, 少数の反対者の所有地が, 周囲の多数者の所有地との一体性が高いために, 一括して扱われて，所有者間での区域設定の対立 を引き起こすということが, 補足的に述べられる。

以上のように，この論文は， 3 地区のみの事例 調査に基づいて考察したもので, 農用地区域決定 の普遍的なメカニズムを解明したとは言い難い。 論文の最後に述べているように，どこにでも当て はまるメカニズムの解明が, 今後の課題であろ う。竹中先生亡き今, 共同研究者は, 大きな支柱 を失なってしまったが, この課題を継続して追究 することを期待したい。 


\section{V 農村計画学会}

竹中先生の晚年の重要な活動のひとつとして, 農村計画学会に関する活動を挙げなければならな い。

周知のように, 農村計画学会は昭和 57 年 4 月に 設立された。その一年半前に設立準備会ができた とき，竹中先生はその世話人を引き受け，設立に 貢献した。設立されてからは, 事務局を竹中先生 の研究室に設置し, 自らは総務委員会委員長とし て活躍するなど, 農村計画学会の運営に重要な役 割を果たした。

農村計画学会の発展を常に願っていたであろう が、それを見届けることができず，思い半ばで倒 れてしまった，誠に残念である。

\section{Vおわりに}

本文中に，内容をくわしく紹介した論文は，竹 中肇教授追悼事業委員会編「農地工学の展開を求 めて一一竹中肇教授論文選集一」に, 解説付き で集録されているので，是非一読されたい。

本文中では, 竹中先生以外の方々の敬称を省略 させていただいた。

竹中先生の業績を紹介するなどという大それた 仕事を、筆者が引き受けたのは，東京大学農学部 小出進教授の強いすすめと激励があったからであ る。本稿の骨組については, 筑波大学社会工学系 佐藤洋平助教授に多くの貴重な助言をいただい た。両氏に深い感謝の意を表したい。

本稿には, 数多くの疵があろうかと思う。ま た，竹中先生の業績を間違って理解していること もあるだろう。これは，ひとえに筆者が責めを負 わなければならない。額にしわをよせて不満げな 表情を見せる竹中先生のお顔が目に浮かぶ。合掌。

\section{参考論文}

1）国土利用動向に沿う林野と農地開発の関係，農 業土木学会誌45（1)，28-36，（畐田正彦 竹 中 肇)，1977

2）農村整備におけるニーズと整備基準一農村総合 整備計画350 事例の分析から一，農業土木学会 論文集76,54-60, (佐藤洋平・富田正彦・竹 中 肇・鈴木元和)

3）農振白地農用地発生要因の分析一優良農用地保 全の観点からのゾーニング制度の合理的あり方 に関する研究 $(1)$ 一, 農業土木学会論文集 92 , 71-79, (広田純一・富田正彦・竹中 肇・菊 嘉宣)，1981

4）優良農用地保全の観点からのゾーニングのため の土地利用区分手法一優良農用地保全の観点か らのゾーニング制度の合理的あり方に関する研 究 (II) 一, 農業土木学会録文集93，71，－78 (広田純一・冨田正彦・竹中 肇)，1981

5) 農村整備から農業地域再開発へ一国土利用秩序 の再構築を担う次世代土地改良事業の枠組一, 農業土木学会誌49（10)，17-23，（富田正彦· 竹中 整), 1981

6）土地改良事業の総合的性格, 農業土木学会誌51 (3)，1，竹中 肇1983

7）農村総合整備の今後の方について, 農村計画 学会誌 1 （2），55-65，(大石純夫・竹中肇)， 1983

8）農振農用地区域の決定メカニズムの分析一土地 利用制御に対するゾーニングの機能に関する実 証的研究（I）一, 農業土木学会論文集 109 , 17-25, (広田純一・富田正彦. 竹中 肇), 1984

9）土地分級一土地改良と土地利用計画のために一, （西口 猛監修）第 2 章「農用地開発における 土地分級」 $(31-52)$ 山路永司 - 佐藤洋平 - 富 田正彦・竹中 肇, 農林統計協会, 1981 


\section{A Study of Domain in Rural Settlements Based on the Recognition of Space by Residents \\ by Yoichi ITo \\ (Nippon Institu te of Technology)}

The purpose of this paper, which is a contribution to the study of the spacial order of rural settlements, is to consider the appearance of domain and the primary factors affecting it. Everyone's sense of territory is formed individually, but as the subject of this article is village space, two types of domain, village-domain and neighbourhood-domain, are examined.

The research was conducted in 12 settlements in four prefectures, using the sign-map method for measuring domain. The main results are as follows:

1) The neighbourhood-domain tends to overlap the smallest communal unit, called 'han'. But when the houses stand along a road, the neighbourhood-domain extends along the road, and when the houses are scattered, it extends around those scattered houses.

2) The village-domain tends to overlap the residential area of the village. Its shape is affected by geographical features as well as the activities of social organizations.

3) The village center, which is used for activities, the main road, which is used in daily life, and the village entrance, which marks the border with other villages, are related to each other.

In conclusion, the spacial structure of a village is made clear by village-domain, neighbourhooddomain, the village center, the main road and the village entrance.

\section{The Late Professor Takenaka's Contribution to Rural Planning Research \\ by Taiichi SAKUMA \\ (Institute of Agriculture and Forestry Engineering, University of Tsukuba)}

This may 14 is the first anniversary of Professor Takenaka's death. I should like to dedicate this article to the memory of the late Professor Takenaka by tracing his contribution to rural planning research.

He began to study rural planning in 1976. His studies and activities covered integrated rural improvement, the settlement of rural areas and land use. Nine related papers written by him are taken up here in chronological order, and the five main papers are explained in detail. They are:

1) The Needs and Level of Improvement in Rural Areas.

2) An Approach to Integrated Rural Development for the Future.

3) The Comprehensive Character of Land Improvement Projects.

4) The Relationship between Forest and Farm Land Reclamation from the Viewpoint of National Land Use.

5) Analysis of the Decision-making Mechanism for Agricultural Land Zones.

This article also refers to his major contribution to the establishment and management of the Rural Planning Association. 